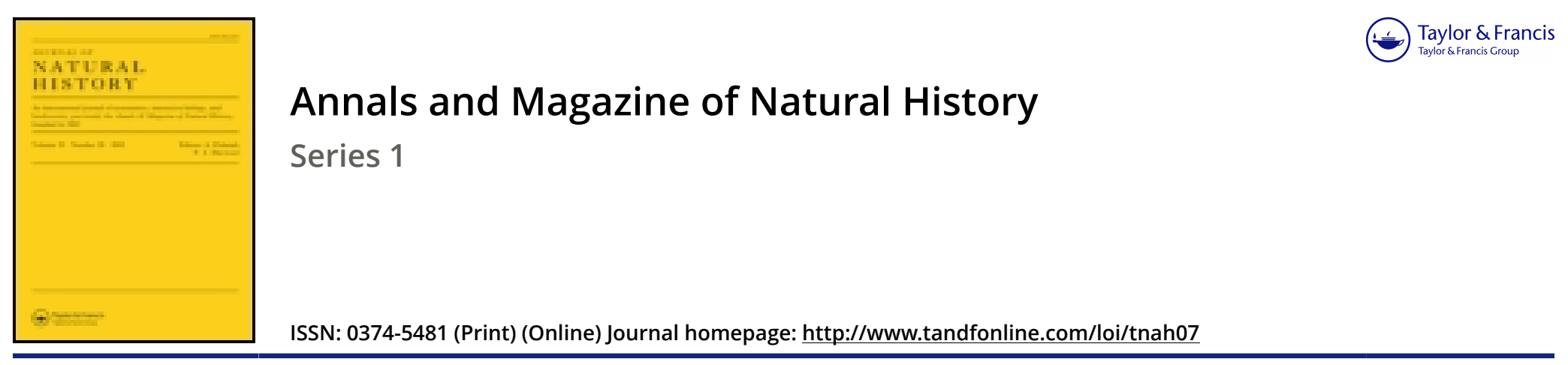

\title{
XVIII.-On the organic origin of the Potstones or Paramoudras of Whitlingham, near Norwich
}

\section{Prof. Ehrenberg}

To cite this article: Prof. Ehrenberg (1838) XVIII.-On the organic origin of the Potstones or Paramoudras of Whitlingham, near Norwich, Annals and Magazine of Natural History, 2:9, 161-162, DOI: $10.1080 / 00222933809512365$

To link to this article: http://dx.doi.org/10.1080/00222933809512365

$$
\text { 册 Published online: } 15 \text { Mar } 2010 .
$$

Submit your article to this journal $\lceil\pi$

Q View related articles $₫$ 


\section{ANNALS OF NATURAL HISTORY.}

XVIII.-On the Organic Origin of the Potstones or Paramoudras of Whitlingham, near Norwich. By Prof. Eurenibera of Berlin.

A $\mathrm{T}$ the late Mecting of the British $\Lambda$ ssociation in Newcastle, Mr. Lyell made a very interesting communication on the vertical funnel-shaped flint tubes, threc feet in length and one in width, which are filled with chalk, and traverse the horizontal layers of chalk near Norwich and in Ireland. Mr. Lyell intimated that these flint tubes, known by the local name of Potstones or Paramoudras, would probably be found to consist of microscopic organized beings, similar to those which had bcen discovered 'in other chalk flints. Prof. Sedgwick was ratt er of opinion that they had the appearance of being merely petrificd fungi, since they quite resembled some forms of large living sponges. Dr. Buckland, who had formerly considered them of organic origin*, at present abandoned this opinion, and vicwed them rather as a product of the chemical separation of the silica from its mixture with the chalk, supporting himself by direct experiments which had exhibited similar phænomena.

This difference of opinion among geologists of such eminence and so universally csteemed, induced me to submit these stones to a direct microscopic examination. During my stay in London in September I obtained from the museum of the Geological Socicty some small fragments of two of these Paramoudras, which have exactly the form of large specimens of Spongia Infundibulum. The microscopic examination determined the organic nature of these masses. I failed to discover in the interior of the stone the structure of well-preserved sponges, which the cxtcrior forms represented, and perceived only contorted remains of decomposed vegetables (probably in-

* Sce Trans. of Geol. Soc. First Series, vol. iv. p. 413. where figures of them are given.-EDit.

Ann. Nat. Hist. Vol, 2. No. 9. Nov. 1838. 


\section{Prof. Ehrenberg on the Origin of the Paramoudras.}

deed sponges), and among these, along with many imperfect specimens, some wcll-prescrved microscopic Polythalamia, shells, and Infusoria, of the same species which I have found diffused in like manner in all flints from the chalk, and which therefore very probably may have had great influence at the formation of these very extensive layers of stone. I also readily recognised well-preserved examples of Xanthidium pilosum and fragments of $X$. ramosum*, together with the Polythalamia, which $I$ have mentioned in my memoir on the Berlin flints.

The sinking of this silica, deriving its origin from organic fragments, by its own gravity, in a funnel shape, through a more solid but naturally still soft layer of chalk, may probably be explained from local circumstances (perhaps from air cavities), which caused the yielding of the yet soft subjacent chalk, where large horizontal flat masses of silica had collected, and could in its pulpy state still sink in the form of a funnel, when the superior layer of chalk pressing down on it formed the core. A heavier body coming from the upper layers of chalk may also have here and there slowly sunk through the soft siliceous masses into the under layer of chalk, and have lcft these flint funnels behind as indicators of its passage. In the first case, the funnel would always be found closed at the bottom; in the latter open at the top and bottom. In each case it would always be wider at the top and narrower at the bottom. If the flint funnels stood with their wider aperture directed downwards, a penetrating force may have procecded from below upwards, and in this way ascending gases may have operated. Local observations will easily explain further this interesting phænomenon. The circumstance of the other contemporaneous forms of the English layers of flints being for the greater part compressed in flattened plates, speaks against the supposition that they were well-preserved sponges in which Infusoria and Mollusca happened to be living; and also the remaining upright of such large soft forms is not at all probable; nor does the existing internal structure in any way favour this view.

EirrenberG.

- Drawings of these two as well as of several other species of Xanthilium necurring in the English flints will bo found in the plates illustrating the Rev. J. 3 . Reade's Paper in the present number.-- Edr. 